Research Article

\title{
Kinetic of Biogas Production in a Batch Anaerobic Digestion Process with Interference of Preservative Material of Sodium Benzoate
}

\author{
Indro Sumantri*, H. Hadiyanto \\ Department of Chemical Engineering, Faculty of Engineering, Universitas Diponegoro, Semarang, \\ Indonesia.
}

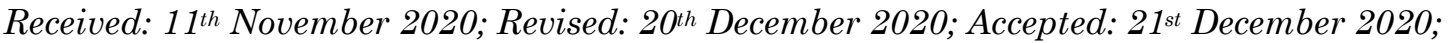
Available online: 22th December 2020; Published regularly: December 2020

\begin{abstract}
Sodium benzoate is a preservative compounds which are widely used for both food and beverage products. The treatment of waste water containing this compound was normally conducted in a anaerobic digestion (AD) using a batch reactor system at a room temperature. The anaerobic process eventually produced biogas which can be used for bioenergy. This research was aimed to evaluate the production of biogas from by synthetic solution models containing sodium benzoate (SB). The experiment was performed in a variation of Mixed Liquor Suspended Solid (MLSS) of 4.8 and $7.2 \mathrm{~g} / \mathrm{L}$, and initial sodium benzoate concentration of 400,600 , and $800 \mathrm{mg} / \mathrm{L}$. The digestion was performed at 60 days, while the biogas content was measured every 2 days. The results indicated a reduction in the cumulative biogas by the addition of sodium benzoate, compared to the control condition. Moreover, the decrease in organic loading rate (OLR) of SB in wastewater follows the first order kinetic with kinetic rate constant $(k)$ was 0.0432 to $0.1254\left(\right.$ day $\left.^{-1}\right)$ for MLSS of $4.8 \mathrm{~g} / \mathrm{L}$ and 0.0276 to $0.0372\left(\right.$ day $\left.^{-1}\right)$ for $7.2 \mathrm{~g} / \mathrm{L}$ MLSS. Copyright ( $) 2020$ BCREC Group. All rights reserved
\end{abstract}

Keywords: Sodium benzoate; Anaerobic digestion; Biogas; First-order kinetic; Batch

How to Cite: Sumantri, I., Hadiyanto, H. (2020). Kinetic of Biogas Production in a Batch Anaerobic Digestion Process with Interference of Preservative Material of Sodium Benzoate. Bulletin of Chemical Reaction Engineering \& Catalysis, 15(3), 898-906 (doi:10.9767/bcrec.15.3.9366.898-906)

Permalink/DOI: https://doi.org/10.9767/bcrec.15.3.9366.898-906

\section{Introduction}

Anaerobic digestion (AD) is the most suitable treatment for extremely polluted organic wastewater (over $4000 \mathrm{mg} / \mathrm{L}$ biodegradable COD) and is therefore appropriate for industrial effluent due to the high Chemical Oxygen Demand (COD), energy generation potential and minimal sludge production [1]. This com-

\footnotetext{
* Corresponding Author.

Email: indrotekim@yahoo.com (I. Sumantri);

Telp.: +6225 7460058; Fax.: +6225 7460058
}

plex biochemical degradation reaction requires several microorganisms and little or no oxygen. In addition, hydrolysis, acidification, acetogenesis and methanogenesis occur simultaneously to produce biogas (a mixture containing 40-70\% $\mathrm{CH}_{4}$ and $\mathrm{CO}_{2}$ ) as the final product. This process is very efficient in removing organic substances, generates little residue ( $10 \%$ of COD content) and is as a result, a promising sustainable economical technology [2,3]. Also, there is a current rise in fascination with $\mathrm{AD}$, particularly in bioreactor development technology, for application in the production of bio-fuel from solid waste. 
Therefore, the generation of renewable energy from refuse and sewage is considered a national strategy for power management [4].

Anaerobic digestion requires certain environmental conditions to generate optimum yield and any chemical substances present may hinder this process. One of the condition is the existence of inhibitor include certain acids (especially benzoic acid), bases, strong oxidizing or reducing agents as well as halogens and their salts [5].

According to Kiel et al. [6], benzoic acid is an essential starting material for synthesizing various products in the chemical industry including food preservatives, artificial flavors and insect repellent. Also, sodium benzoate, the derivative salt is popularly used to increase the food and beverage shelf-life by eliminating micro-organism growth $[7,8,9]$. SB is a salt of benzoic acid which is effective to attack wide range of bacterial and also to inhibit the growth of yeast and mold [10]. Benzoic acid is one of the effluents of agro-industrial and food processing activities. This substance is classified as low biodegradability and increased toxicity [11]. In the Terephthalic acid (TPA) manufacturing contributes high COD content up to $75 \%$ [12]. Benzoic acid accumulation in wastewater occurs due to of its production and application. This wastewater is potential to deteriorate the ecosystem and human health, treatment of this wastewater is an obligation before discharging into receiving water bodies. How to treat or remove the benzoic acid content in the wastewater is still a big challenge [13].

Wang et al. [14] disclosed anaerobic digestion as an effective approach towards the treatment of phenolic wastewater and SB is the derivation of phenolic substance [15]. Therefore, this study aims to discover the salt's influence on $\mathrm{AD}$. The $\mathrm{AD}$ process utilizes an activated sludge to degrade SB, activated sludge plays an important role in the decomposition process, and operated under a batch concentration sys-

Table 1. Variation of activated sludge and SB solution (Activated sludge: $12 \mathrm{~g} / \mathrm{L}$ ).

\begin{tabular}{ccc}
\hline \multicolumn{2}{c}{$\%$ volume } & Concentration \\
$\begin{array}{c}\text { activated } \\
\text { sludge }\end{array}$ & $\begin{array}{c}\text { SB } \\
\text { solution }\end{array}$ & \\
\hline 0 & 100 & \\
40 & 60 & \\
60 & 40 & 400,600, and 800 \\
100 & 0 & \\
\hline
\end{tabular}

tem with SB. Also, the reaction's completion is indicated by biogas formation. Hence, the experiment was conducted over sixty days and the biofuel produced was measured every two days and the synthesis' kinetic model was also studied.

\section{Materials and Methods}

\subsection{Materials}

SB was obtained of Sigma-Aldrich Corp (purity $>98 \%$ ). To set up the $\mathrm{pH}$ into $\mathrm{pH}$ of experiments used sodium hydroxide or hydrochloric acid which obtained from the local chemical store. Sucrose obtained from food store and activated sludge was from wastewater plant of anaerobic system and located at the LamperTengah, Semarang, Central Java, Indonesia. This plant treated wastewater of the centralized wastewater treatment of tofu small-scale industry.

The anaerobic sludge for acclimatization was introduced with $5 \mathrm{~g} / \mathrm{L}$ of sucrose, while $\mathrm{N}$, $\mathrm{P}$ nutrient were provided daily for a period of 2 months. The sludge was measured the concentration of Mixed Liquor Suspended Solid (MLSS), the MLSS designed for experiment was $12 \mathrm{~g} / \mathrm{L}$ by setting the water content [8].

\subsection{Acclimatization of Activated Sludge.}

The Centralized Wastewater Treatment Plant in Lamper Tengah, Semarang, manages wastewater for small-scale tofu industries and generates the anaerobic sludge used in this study. A Water sampler was used to take activated sludge in the bottom of the anaerobic tank. The sample was collected in a plastic tank and conveyed to the laboratory. The anaerobic sludge was acclimatized in the tank and set at $\mathrm{pH}$ between 7.0-7.5. The anaerobic sludge was acclimatized in the tank and set at $\mathrm{pH}$ between 7.0-7.5 by using aqueous solution of sodium hydroxide or hydrochloric acid depending on the nature of the circumstance of acid or base.

\subsection{Experimental Set-up}

Batch system was conducted in bottles containing activated sludge and SB solution mixed at various compositions (Table 1). The anaerobic reactors were designed for batch system and the reaction was performed local room temperature $\left(31-33^{\circ} \mathrm{C}\right)$, at room temperature. In addition, liquid displacement method was adopted to measure biogas production during the digestion. Syaichurrozi et al. [16] reported the method as often exploited by previous re- 
searchers. The measurements were collected by connecting the digester to a gas collector with a gradual cylindrical glass, and the channel terminal was immersed in water to ensure complete sealing. Therefore, biogas yield was collected by the downward displacement of water.

\subsection{Experimental Design}

Table 1 shows the experiment variables, and the COD of SB solution was analyzed according to the procedures recommended by APHA [17] in the Standard methods for examining water and waste water. Control condition was conducted to the research by set up the system of $100 \%$ of activated sludge and $0 \%(100 \% \mathrm{SB})$.

\subsection{Experimental Procedures}

$\mathrm{AD}$ process adopted in the biogas formation was used to investigate the effect of SB substance in the anaerobic system. Therefore, the ratio of SB substrate-activated sludge was varied in the system to assess the variations in

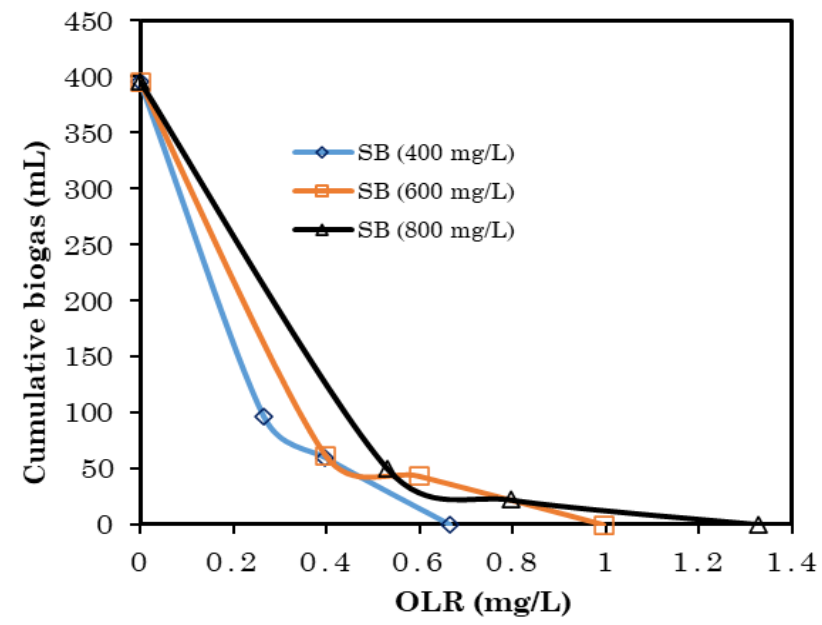

Figure 1. Cumulative of biogas production for various OLR and of activated sludge only $(12 \mathrm{~g} / \mathrm{L})$. mixture substrate composition. This was calculated based on the sludge percent volume ratio against the SB solution $(0 \%, 20 \%, 40 \%, 60 \%$, $80 \%$, and $100 \%$ volume). The system $\mathrm{pH}$ was set at 7.0-7.5, using a $2 \mathrm{~N} \mathrm{NaOH}$ solution, while the technical-grade was used to prepare $\mathrm{NaOH}$ solution.

The anaerobic reactor was operated in a batch system. The plastic bottle volume for experiment was $2 \mathrm{~L}$. The bottles of polyethylene were made as anaerobic reactors. These bottle reactors have been plugged with rubber plug and equipped with valve to measure biogas production. Therefore, the digestion process was conducted for 60 days, while the degradation duration was proposed with reference to previous researchers on biogas production $[18,19]$. The quantity formed during digestion was measured every two days, using water displacement method, and each medium was stirred manually for one minute daily.

\section{Results and Discussions}

\subsection{Organic Loading Rate (OLR)}

The SB (mg/L) concentration was converted to $\mathrm{mg} \mathrm{COD} / \mathrm{L}$ in order to indicate the variables' organic loading rate (OLR). Therefore, pure SB was analyzed by dissolving $1 \mathrm{~g}$ into $1 \mathrm{~L}$ distilled water. Subsequently, the COD content was evaluated, and the triple sample results indicate a relation of $1,000 \mathrm{mg} / \mathrm{L} \mathrm{SB}$, equivalent to $1,658.77 \mathrm{mg}$ COD/L. The OLR for batch system was calculated with the following equation:

$$
O L R=\frac{V \times C}{V_{T}}
$$

where OLR is the Organic Loading Rate, $V$ is the volume of $\mathrm{SB}(\mathrm{mL}), C$ is the concentration (mg COD/L), and $V_{T}$ is the total volume $(\mathrm{mL})$. Also, Table 1 is then written as Table 2 under this circumstance.

Table 2. MLSS, OLR and accumulation of biogas production.

\begin{tabular}{cccccc}
\hline \multirow{2}{*}{$\begin{array}{l}\text { Concentration } \\
\text { of MLSS (g/L) }\end{array}$} & $\begin{array}{c}\text { Volume activated } \\
\text { sludge (mL) }\end{array}$ & $\begin{array}{c}\text { Volume of SB } \\
\text { solution (mL) }\end{array}$ & $\begin{array}{c}\text { SB } \\
\text { concentration } \\
(\mathrm{mg} / \mathrm{L})\end{array}$ & $\begin{array}{c}\text { OLR } \\
(\mathrm{g} \text { COD/L) }\end{array}$ & $\begin{array}{c}\text { Cumulative biogas } \\
(\mathrm{mL})\end{array}$ \\
\hline 0 & 0 & 2000 & - & - & 0 \\
\hline 4.8 & 800 & 1200 & 400 & 0.398 & 59.6 \\
& & & 600 & 0.597 & 43.4 \\
& 1200 & 800 & 800 & 0.796 & 22.0 \\
\hline 7.2 & & & 400 & 0.265 & 96.4 \\
& & & 600 & 0.398 & 61.8 \\
\hline 12 & 2000 & 0 (control) & - & - & 49.6 \\
\hline
\end{tabular}




\subsection{Biogas Production}

Figure 1 shows cumulative biogas production of OLR function for various concentration of SB (400 to $800 \mathrm{mg} / \mathrm{L})$. The starting point is the control point (OLR:0), i.e. the reactor contains only activated sludge without the addition of SB. Biogas production is highly dependent on OLR value, the higher the OLR value, the resulting biogas will be reduced. If the concentration of SB increases then OLR also increases, the results show the cumulative biogas production will be lower. OLR values will increase at SB concentrations of 400,600 , and $800 \mathrm{mg} / \mathrm{L}$ and biogas shows lower yields, for SB $400 \mathrm{mg} / \mathrm{L}$ with OLR of 0.398 and $0.265 \mathrm{~g}$ $\mathrm{COD} / \mathrm{L}$ resulted cumulative biogas of 59.6 and $96.4 \mathrm{~mL}$ ), SB $600 \mathrm{mg} / \mathrm{L}$ with OLR of 0.597 and $0.398 \mathrm{~g} \mathrm{COD} / \mathrm{L}$ resulted cumulative biogas of 43.4 and $61.8 \mathrm{~mL}$ ), and SB $800 \mathrm{mg} / \mathrm{L}$ with OLR of 0.796 and $0.531 \mathrm{~g} \mathrm{COD} / \mathrm{L}$ resulted cumulative biogas of 22.0 and $49.6 \mathrm{~mL}$ ).

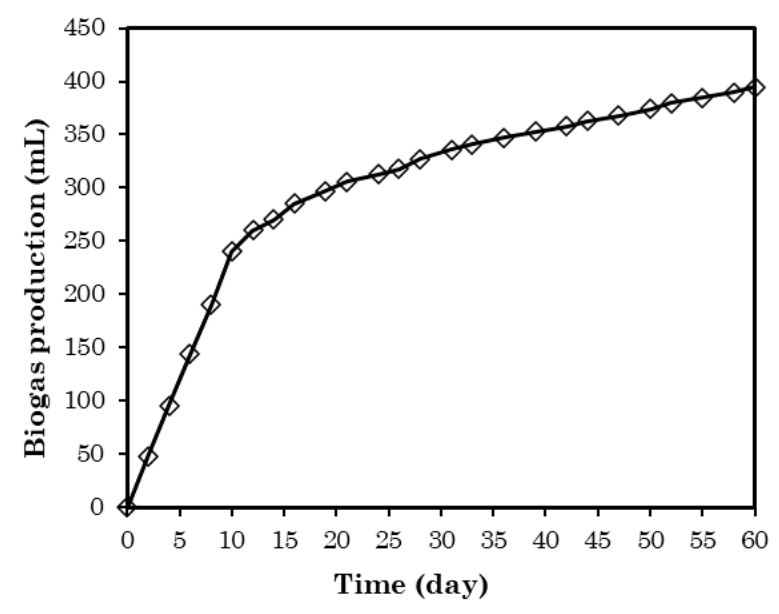

Figure 2. Cumulative of biogas production of activated sludge only $(12 \mathrm{~g} / \mathrm{L})$.

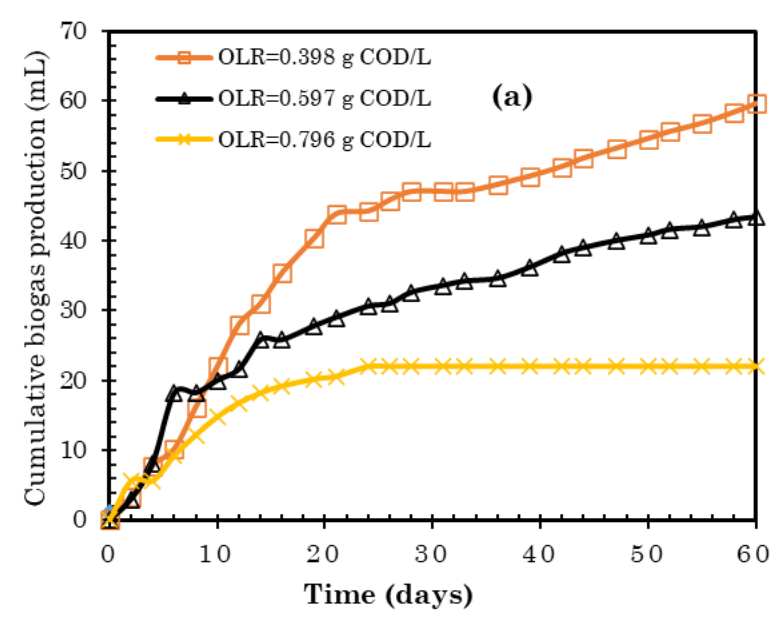

In $\mathrm{AD}$ process, increasing OLR of organic substances will significantly produce amount of biogas, the bacteria to produce methane depends on the availability of organic acids and also bacteria of acid and acetate to produce hydrogen [20]. The function of SB as a preservative substance is to prevent the growth of microorganisms [21]. Increasing the SB will increase the substance to inhibit the growth of microorganisms. Furthermore, the biogas production decreased with more SB solution in the digester.

For batch system with $100 \%$ of SB solution, the biogas has no produced. This is because the properties of SB as preservative materials to maintain the food product stay longer period by prevent the growth of microorganisms [22]. SB in the activated sludge will suppress the growth of microorganisms and will reduce the activity to degrade the organic substances.

Figure 2 shows control conditions for 100\% activated sludge (MLSS:12 g/L) and 0\% (100\% SB). Activated sludge condition of $0 \%(100 \%$ SB) does not produce biogas during 60-day observations while for activated sludge $100 \%$ produces biogas such as Figure 2. On the curve shows that in the first 10 days anaerobic digestion produces high biogas. This was due to entrapped air which can be utilized by microorganisms in the reactor [23]. At the first 10 days digestion, the biogas production was high. Formation of biogas started after inoculation and increase until achieved the peak [24]. Usually, the formation of methane was followed by reduction of $\mathrm{pH}$, range $\mathrm{pH}$ of methanogenic process were found to lie within (6.5-8).

Figure 3 (a) and (b) indicated the yield of biogas of MLSS of $4.8 \mathrm{~g} / \mathrm{L}$ and $7.2 \mathrm{~g} / \mathrm{L}$ with various value of OLR in the system. SB in the water will be found in the form of benzoic acid.

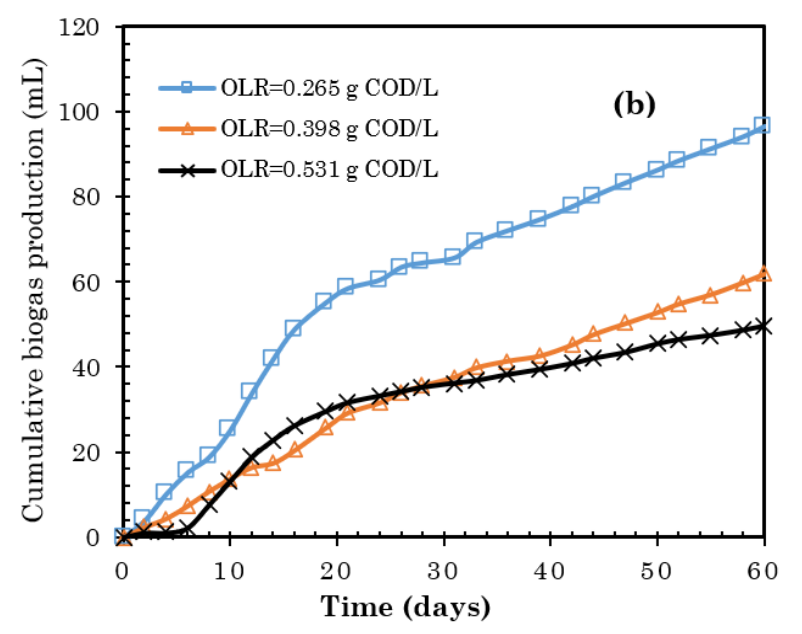

Figure 3. Cumulative of biogas production with MLSS concentrations of (a) $4.8 \mathrm{~g} / \mathrm{L}$ and (b) $7.2 \mathrm{~g} / \mathrm{L}$. 
Benzoic acid in the $\mathrm{AD}$ process will degrade through ring fission and acetogenesis to form 3 Acetate $+\mathrm{CO}_{2}+3 \mathrm{H}_{2}$, and further process via methanogenesis will be obtained $\mathrm{CH}_{4}$ and $\mathrm{CO}_{2}$ [25]. The cumulative of the system with MLSS of $4.8 \mathrm{~g} / \mathrm{L}$ for various OLR $(0.398,0.597$ and $0.796 \mathrm{~g} \mathrm{COD} / \mathrm{L})$ and MLSS of $7.2 \mathrm{~g} / \mathrm{L}$ for various OLR (0.265, 0.398 and $0.531 \mathrm{~g}$ COD/L) obtained cumulative of biogas production was lower than in system that only 100\% MLSS. This indicated that the effect of the SB interfere to the batch anaerobically reactor.

Figure 3 (a) for MLSS of $4.8 \mathrm{~g} / \mathrm{L}$ shown the fast response of microorganisms in the anaerobic system to the substrates. During 4-6 days of digestion, the cumulative of biogas formation results almost similar. After 6 days digestion, the formation of biogas follows as the organic load. Low organic load of SB will produce biogas greater than those which have higher organic load. OLR of $0.398 \mathrm{~g}$ COD/L has higher biogas production than OLR of 0.597 and 0.796 g COD/L, respectively. The cumulative biogas production of $0.398 \mathrm{~g}$ COD/L increased until 60 days observation while the production pattern of biogas was similar for OLR of $0.597 \mathrm{~g}$ COD/L. Both these OLR (0.396 and $0.597 \mathrm{~g}$ $\mathrm{COD} / \mathrm{L}$ ) until 60 days digestion haven't indicated the digestion was complete because the curve was still increase even though with low production. While for OLR of $0.796 \mathrm{~g}$ COD/L indicated that at the day of 24 days and further resulted the constant curve and it indicated that there was no formation of biogas in this condition.

Comparison to the batch system for fully activated sludge, for MLSS of $4.8 \mathrm{~g} / \mathrm{L}$ the cumulative biogas production dropped significantly from $395 \mathrm{~mL}$ to $59.6 \mathrm{~mL}, 43.4 \mathrm{~mL}$ and $22 \mathrm{~mL}$. The SB solution interfere the production biogas through the elimination of the microorganisms or reduce the activity the microorganisms to degrade organic substances [21,22]. Increasing the OLR will affect to the reduction of formation of biogas because higher OLR required significant amount of microorganisms to overcome.

While for Figure 3 (b) for MLSS of $7.2 \mathrm{~g} / \mathrm{L}$ with OLR of $0.265,0.398$, and $0.531 \mathrm{~g} \mathrm{COD/L}$ resulted that the cumulative of biogas production higher than for MLSS of $4.8 \mathrm{~g} / \mathrm{L}$. Increasing the MLSS of activated sludge improved the degree of biogas production. Three curves for different OLR shown that until 60 days were higher than of MLSS of $4.8 \mathrm{~g} / \mathrm{L}$, those curves also indicated that the cumulative biogas production haven't achieved the constant value which occurred due to the completion of degradation and the cumulative biogas production of from high to low production follow the OLR of 0.265 $>0.398>0.531 \mathrm{~g} \mathrm{COD} / \mathrm{L}$.

Comparison of Figure 2 and Figures 3(a) and (b) indicated the curve profile of different condition between without and with SB, and based on the curves shown that significant reduction of biogas production with the treatment of SB. SB which broadly used as preservative material of variety product of foods and beverages. It is usually effective to prevent or inhibit the growth of microorganisms (mold and yeast) and attacks a wide range of bacteria $[10,26]$. Researchers have been investigate the effect of the SB as chemical preservative both to human and microbial. The effect of the addition SB in the system was reduce the amount of microorganisms or reduce the rate of biogas formation. Application of SB as preservative material is still doubtful and various research conducted the effect of SB to the human and microbial are intensively investigated.

There was evidence that addition the SB to the system caused reduction of the biogas production. In the batch system of $\mathrm{AD}$, application of SB as preservative material reported that the negative effect of preservative material (SB) gradually increases with the exposure time. Experiment to the human activity of endoproteinases which in contact with a preservative indicate negative effect of food preservative at the molecular level of organisms [27]. Study to utilize SB as washing solution of postharvest tomatoes in order to decontaminate of bacterial pathogens obtained that SB effectively reduced the background of yeast and molds without change the color [28]. Intensive experiment using zebrafish larva of SB to the effect of larva growth appeared the abnormality of growth and test of LC50 with approximately $400 \mathrm{ppm}$ for 48 hours of SB exposure induced toxicity [22], in soymilk samples was found able to prevent the growth of food borne microorganisms [29], SB killed E. coli and Staphylococcus aureus after preserve for 2 and 24 hours treatment [30], applied to preserve in the juice of fruit able to decrease the load of microbial [31] has disadvantage to the cell damage [32].

\subsection{Kinetic Study}

The performance of batch anaerobic digestion process can be used to predict the completion of the anaerobic process (hydrolysis, acidogenesis, acetogenesis, and methanogenesis) and it can be measured through kinetic studies. Study of kinetic has also given beneficiary to help the understanding of mechanisms of in- 
hibitory degradation. The simplest model for kinetic model is the first-order kinetic model, it can be applied to explain the degradation of complex substrate in anaerobic digestion and also the simplest model for stable process under practical conditions. The first-order kinetic model was used to the availability of substrate limiting factor [23]. The first-order kinetic equation is:

$$
\frac{d C}{d t}=-k C
$$

where $d C / d t$ is the reduction of the substrate concentration, $k$ is the rate constant of firstorder substrate utilization $\left(\right.$ time $\left.^{-1}\right)$, and $C$ is the biodegradable substrate concentration $(\mathrm{mg} / \mathrm{L})$. Equation (2) can be integrated with limiting value resulted:

$$
C=C_{0} e^{-k t}
$$

where $C_{0}$ is initial substrate concentration $(\mathrm{mg} / \mathrm{L})$. The biogas production in the batch system can be correlated to the concentration of the biodegradable substrate and the equation

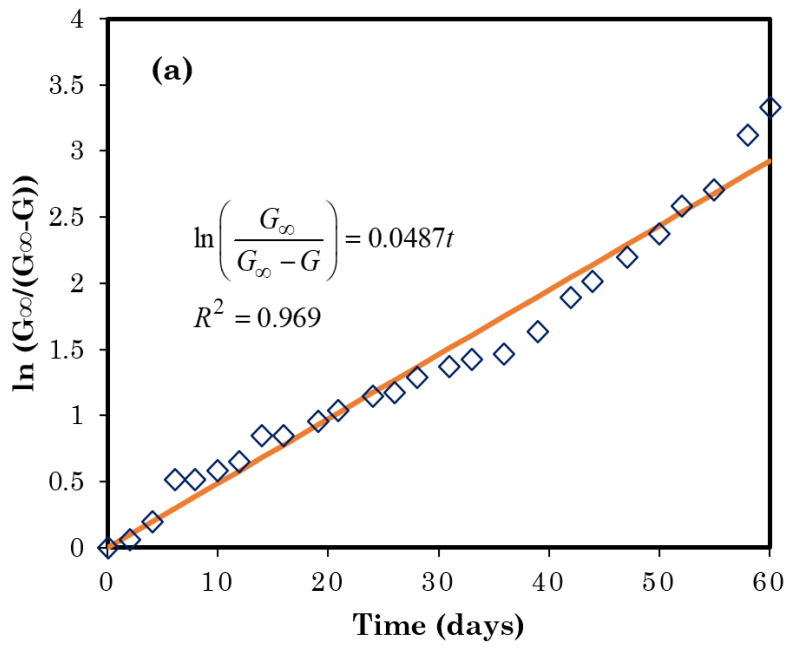

become:

$$
\frac{G_{\infty}-G}{G_{\infty}}=\frac{C}{C_{0}}
$$

where $G_{\infty}$ is the ultimate biogas production. Equation (2) and (3) can be combined and integrated for model of first-order kinetic and this gives a correlation between the biogas production and time required for degradation.

$$
G=G_{\infty}\left(1-e^{-k t}\right)
$$

In this relation, $\mathrm{k}$ is the constant rate of firstorder biogas production. The further solution of the equation (5) is:

$$
\ln \left(\frac{G_{\infty}}{G_{\infty}-G}\right)=k t
$$

This is the straight line curve if plotting the data of $\ln \left(G_{\infty} /\left(G_{\infty}-G\right)\right.$ versus $t$. The slope is equal to $k$ with setting up the intercept of zero (it is assumed that there is no biogas formation at the time of zero). The value of $G_{\infty}$ is considered equal to the cumulative biogas production at the end of each experiment. The value of the

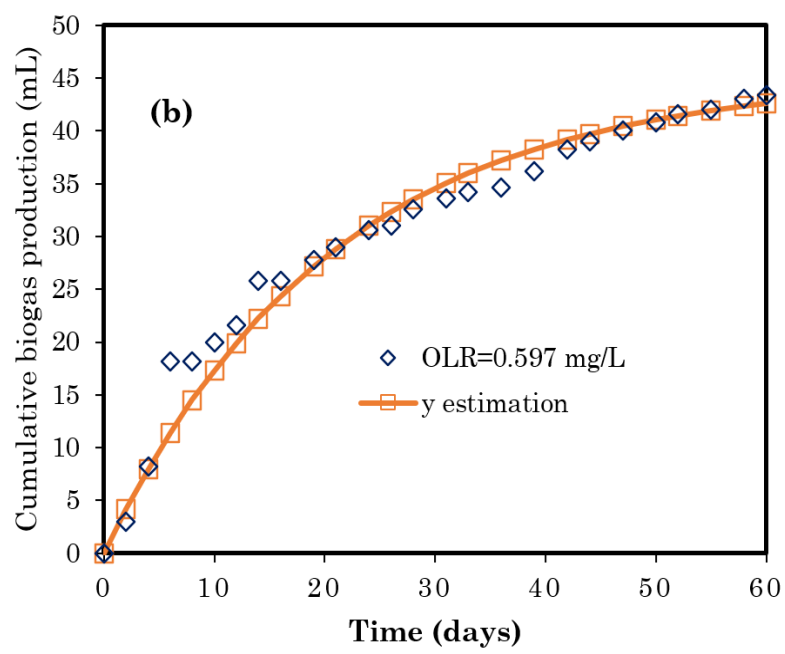

Figure 4. (a) Example plot for determination of kinetic constant (k) and (b) comparison yield of biogas of experiment and model.

Table 3. Kinetic study of anaerobic digestion process of batch system.

\begin{tabular}{ccccccc}
\hline \multirow{2}{*}{$\begin{array}{c}\text { Concentration of } \\
\text { MLSS }(\mathrm{g} / \mathrm{L})\end{array}$} & $\begin{array}{c}\text { Volume of SB } \\
\text { solution }(\mathrm{mL})\end{array}$ & $\begin{array}{c}\text { SB concentration } \\
(\mathrm{mg} / \mathrm{L})\end{array}$ & $\begin{array}{c}\text { OLR } \\
(\mathrm{g} \text { COD/L) }\end{array}$ & $G_{\infty}(\mathrm{mL})$ & $k\left(\right.$ day $\left.^{-1}\right)$ & $\mathrm{R}^{2}$ \\
\hline 0 & $2000($ control $)$ & - & - & - & - & - \\
\hline 4.8 & 1200 & 400 & 0.398 & 63 & 0.0432 & 0.966 \\
& & 600 & 0.597 & 45 & 0.0487 & 0.969 \\
& & 800 & 0.796 & 22 & 0.1254 & 0.980 \\
\hline 7.2 & 800 & 400 & 0.265 & 103 & 0.0377 & 0.963 \\
& & 600 & 0.398 & 71 & 0.0276 & 0.955 \\
& & 800 & 0.531 & 54 & 0.0372 & 0.977 \\
\hline 12 & 0 (control) & - & 0 & 404 & 0.0569 & 0.958 \\
\hline
\end{tabular}


$G_{\infty}$ is can be calculated by Excel program and the straight line is the value of $k$. The result of this experiment shown in the Table 3 and Figures 4 (a) and (b).

The cumulative biogas production at the MLSS of $4.8 \mathrm{~g} / \mathrm{L}$ and $7.2 \mathrm{~g} / \mathrm{L}$ at the room temperature, the value of the rate of constant of first-order kinetic, the value of $G_{\infty}$ and regression coefficients $\left(\mathrm{R}^{2}\right)$ with the model described in Equation (4) shown in Table 3, Figures 4 (a) and (b) indicated an example plot for determination of kinetic constant $(k)$ and comparison yield of biogas of experiment and model (b). The value of $G_{\infty}$ decreased with increased of OLR both for MLSS of 4.8 and $7.2 \mathrm{~g} / \mathrm{L}$, while the value $k$ increased due to increase of OLR. The data of experiments indicated the high significant to the regression coefficients with the value of $\mathrm{R}^{2}$ almost greater than $95 \%$. Figure 4 (a) indicated the example of calculation of $k$ using linearization method and Figure 4 (b) shown between the value of experiments and predicted data $[23,20]$. The value of $k$ at MLSS of $4.8 \mathrm{~g} / \mathrm{L}$ was 0.0432 to $0.1254\left(\mathrm{day}^{-1}\right)$ and for MLSS of $7.2 \mathrm{~g} / \mathrm{L}$ was 0.0276 to $0.0372\left(\mathrm{day}^{-1}\right)$ while $\mathrm{k}$ obtained of Beevi [23] was 0.0249 $\left(\right.$ day $\left.^{-1}\right)$.

\section{Conclusion}

The result of the study focused on the batch digester of anaerobic process under room temperature condition. Control variable with activated sludge of $100 \%$ and $0 \%$ (100\% SB) used to evaluate the effect of SB in the system. There is no biogas for activated sludge $0 \%$ (100\% SB). The effect of SB on anaerobic systems indicates an influence on biogas production, there is a siginificant reduction of biogas production if compared with the control condition of $100 \%$ of activated sludge. Increased SB levels indicated by higher OLR values result in lower biogas. Observations for 60 days showed that biogas production is still not finished because it still shows an increase in biogas production even though it is small. The value of $\mathrm{k}$ mostly increased with the elevated OLR while the value of $G_{\infty}$ decreased with increasing the OLR. The regression coefficient with $\mathrm{R}^{2}$ greater than 0.95 indicated that the model of first-order kinetic was suitable for the data.

\section{References}

[1] Sun, L., Wan, S., Yu, Z., Wang, Y., Wang, S. (2012). Anaerobic biological treatment of high strength cassava starch wastewater in a new type up-flow multistage anaerobic reactor. Bioresour. Technol., 104, 280-288. doi: 10.1016/j.biortech.2011.11.070

[2] Kondusamy, D., Kalamdhad, A.S. (2014). Pretreatment and anaerobic digestion of food waste for high rate methane_production - A review. J. Environ. Chem. Eng., 2, 18211830. doi: 10.1016/j.jece.2014.07.024

[3] Cheng, Q., Chen, Z., Deng, F., Liao, Y., Xiao, B., Li, J. (2016). Kinetic evaluation on the degradation process of anaerobic digestion fed with piggery wastewater at different OLRs. Biochemical Engineering Journal, 113, 123132. doi: 10.1016/j.bej.2016.06.010

[4] Jia, J.D., Ma, L.L., Jiang, D.P., Ge, Y.Q. (2014). Development Strategy for the Science and Technology Innovation of Biomass Energy Industry. Chemical Industry Press, Beijing.

[5] Reynolds, T.D., Richards, P.A. (1996). Unit Operations and processes in environmental engineering. Second Edition, PWS Publishing Company, An International Thomson Publishing Company. pp. 30.

[6] Kiel, M., Dobslaw, D., Engesser, K.H. (2014). Comparison of biological and chemical treatment processes as cost-effective methods for elimination of benzoate in saline wastewaters. Water Research, 66, 1-11. doi: 10.1016/j.watres.2014.07.045

[7] Magnuson, B., Munro, I., Abbot, P., Baldwin, N., Lopez-Garcia, R., Ly, K., Socolovsky, S. (2013). Review of the regulation and safety assessment of food substances in various countries and jurisdictions. Food additives \& Contaminants: Part A, 30(7), 1147-1220. doi: 10.1080/19440049.2013.795293

[8] Sumantri, I., Budiyono, B., Purwanto, P. (2019). Kinetic Study of Anaerobic Digestion of Ketchup Industry Wastewater in a Threestages Anaerobic Baffled Reactor (ABR). Bulletin of Chemical Reaction Engineering \& $\mathrm{Ca}$ talysis, 14(2), 326-335. doi: 10.9767/bcrec.14.2.2838.326-335

[9] Birck, C., Degoutin, S., Maton, M., Neut, C., Bria, M., Moreau, M., Fricoteaux, F., Miri, V., Bacquet, M. (2016). Antimicrobial citric acid/poly(vinyl alcohol) crosslinked films: Effect of cyclodextrin and sodium benzoate on the antimicrobial activity. $L W T$ - Food Science and Technology, 68, 27-35. doi: 10.1016/j.lwt.2015.12.009 
[10] Zhang, G., Ma, Y. (2013). Spectroscopic studies on the interaction of sodium benzoate, a food preservative, with calf thymus DNA. Food Chemistry, 141, 41-47. doi: 10.1016/j.foodchem.2013.02.122

[11] Pariente, M.I., Martinez, F., Melero, J. A., Botas, J.A., Velegraki, T., Xekoukoulotakis, N.P., Mantzavinos, D. (2008). Heterogeneous photo-Fenton oxidation of benzoic acid in water: Effect of operating conditions, reaction by-products and coupling with biological treatment. Appl. Catal. B., 85, 24-32. doi: 10.1016/j.apcatb.2008.06.019

[12] Tekin, G., Ersöz, G., Atalay, S. (2018). Degradation of benzoic acid by advanced oxidation processes in the presence of $\mathrm{Fe}$ or Fe-TiO2 loaded activated carbon derived from walnut shells: A comparative study. J. Environ. Chem. Eng., 6, 1745-1759. doi: 10.1016/j.jece.2018.01.067

[13] Chai, K., Ji, H. (2012). Dual functional adsorption of benzoic acid from wastewater by biological-based chitosan grafted bcyclodextrin. Chem. Eng. J., 203, 309-318. doi: 10.1016/j.cej.2012.07.050

[14] Wang, W., Wu, B., Pan, S., Yang, K., Hu, Z., Yuan, S. (2017). Performance robustness of the UASB reactors treating saline phenolic wastewater and analysis of microbial community structure. Journal of Hazardous Materia ls, $\quad 331, \quad 21-27 . \quad \mathrm{d}$ o i : 10.1016/j.biortech.2003.06.004

[15] Jiang, Y., Wei, L., Zhang, H., Yang, K., Wang, H. (2016). Removal performance and microbial communities in a sequencing batch reactor treating hypersaline phenol-laden wastewater, Bioresour. Technol., 218, 146152. doi: 10.1016/j.biortech.2016.06.055

[16] Syaichurrozi, I., Budiyono, B., Sumardiono, S. (2013). Predicting kinetic model of biogas production and biodegradability organic materials: Biogas production from vinasse at variation of COD/N ratio, Bioresource Technology $149, \quad 390-397 . \quad$ d o i : 10.1016/j.biortech.2013.09.088

[17] APHA. (1998). Standard Methods for the Examination of Water and Wastewater, 20th ed. American Public Health Association, Washington, DC, USA.

[18] Budiyono, B., Widiasa, I.N., Johari, S., Sunarso. (2010). The kinetic of biogas production rate from cattle manure in batch mode. Int. J. Chem. Biol. Eng., 3(1), 39-44. doi: 10.12777/ijse.6.1.31-38

[19] Patil, J.H., Raj, M.A., Muralidhara, P.L., Desai, S.M., Raju, G.K.M. (2012). Kinetics of anaerobic digestion of water hyacinth using poultry litter as inoculum. Int. J. Environ. Sci. Dev., 3(2), 94-98.
[20] Ebrahimi, A., Hashemi, H., Eslami, H., Fallahzadeh, R.A., Khosravi, R., Askari, R., Ghahramani, E. (2018). Kinetics of biogas production and chemical oxygen demand removal from compost leachate in an anaerobic migrating blanket reactor. Journal of Environmental Management, 206, 707-714.

[21] Gaur, H., Purushothaman, S., Pullaguri, N., Bhargava, Y., Bhargava, A. (2018). Sodium benzoate induced developmental defects, oxidative stress and anxiety-like behavior in zebrafish larva. Biochemical and Biophysical Research Communications, 502, 364-369. doi: 10.1016/j.bbrc.2018.05.171

[22] Yadav, A., Kumar, A., Das, M., Tripathi, A. (2016). Sodium benzoate, a food preservative, affects the functional and activation status of splenocytes at non cytotoxic dose. Food and Chemical Toxicology, 88, 40-47. doi: 10.1016/j.fct.2015.12.016

[23] Beevi, B.S., Madhu, G., Sahoo, D.K. (2015). Performance and kinetic study of semi-dry thermophilic anaerobic digestion of organic fraction of municipal solid waste. Waste Mana gement, $36, \quad 93-97$. d o i : 10.1016/j.wasman.2014.09.024

[24] Candia-Garcia, C., Delgadillo-Mirquez, L., Hernandez, M. (2018). Biodegradation of rice straw under anaerobic digestion. Environmental Technology \& Innovation, 10, 215-222. doi: 10.1016/j.eti.2018.02.009

[25] Annachhatre, A.P., Gheewala, S.H. (1996). Biodegradation Of Chlorinated Phenolic Compounds, Biotechnology Advances, 14(1), $35-56$.

[26] Lennerz, B.S., Vafai, S.B., Delaney, N.F., Clish, C.B., Deik, A.A., Pierce, K.A., Ludwig, D.S., Mootha, V.K. (2015). Effects of sodium benzoate, a widely used food preservative, on glucose homeostasis and metabolic profiles in humans. Mol. Genet. Metab., 114, 73-79. doi: 10.1016/j.ymgme.2014.11.010

[27] Esimbekova, E.N., Asanova, A.A., Deeva, A.A., Kratasyuk, V.A. (2017). Inhibition effect of food preservatives on endoproteinases. Food Chemistry, 235, 294-297. doi: 10.1016/j.foodchem.2017.05.059

[28] Chen, H., Zhang, Y., Zhong, Q. (2019). Potential of acidified sodium benzoate as an alternative wash solution of cherry tomatoes: Changes of quality, background microbes, and inoculated pathogens during storage at 4 and $21^{\circ} \mathrm{C}$ post-washing. Food Microbiology, 82, 111-118. doi: 10.1016/j.fm.2019.01.013

[29] Agbaka, J.I., Ishiwu, C.N., Ibrahim, A.N. (2020). Effect of Addition of Citric Acid and Sodium Benzoate on $\mathrm{pH}$ and Microbial Profile of Soymilk. Asian Food Science Journal, 15 ( 4 ), $21-31 . \quad \mathrm{d}$ o i : 10.9734/AFSJ/2020/v15i430158 
[30] Selim, S.A., El Alfy, S.M., Aziz, M.H.A., Mashait, M.S., Warrad, M.F. (2012). Evolution of Bactericidal Activity of Selected Food Additives against Food Borne Microbial Pathogens. Biosciences Biotechnology Research Asia, 9(1), 7-17.

[31] Nwachukwu, E., Ezeigbo, C.G. (2013). Changes in the microbial population of pasteurized soursop juice treated with benzoate and lime during storage. African Journal of Microbiology Research, 7(31), 3992-3995. doi: 10.1080/19440049.2013.795293
[32] Shahmohammadi, M., Javadi, M., NassiriAsl, M. (2016). An Overview on the Effects of Sodium Benzoate as a Preservative in Food Products. Biotech. Health Sci., 3(3), 35084. doi: 10.17795/bhs-35084 